\title{
HVMANITAS
}

O uso do símile no poema A Tomada de Tróia de Trifiodoro

Autor(es): $\quad$ Pinheiro, Joaquim

Publicado por: Imprensa da Universidade de Coimbra

URL

persistente:

URI:http://hdl.handle.net/10316.2/44777

DOI:

DOI:https://doi.org/10.14195/2183-1718_72_4

Accessed : $\quad$ 26-Apr-2023 12:52:07

A navegação consulta e descarregamento dos títulos inseridos nas Bibliotecas Digitais UC Digitalis, UC Pombalina e UC Impactum, pressupõem a aceitação plena e sem reservas dos Termos e Condições de Uso destas Bibliotecas Digitais, disponíveis em https://digitalis.uc.pt/pt-pt/termos.

Conforme exposto nos referidos Termos e Condições de Uso, o descarregamento de títulos de acesso restrito requer uma licença válida de autorização devendo o utilizador aceder ao(s) documento(s) a partir de um endereço de IP da instituição detentora da supramencionada licença.

Ao utilizador é apenas permitido o descarregamento para uso pessoal, pelo que o emprego do(s) título(s) descarregado(s) para outro fim, designadamente comercial, carece de autorização do respetivo autor ou editor da obra.

Na medida em que todas as obras da UC Digitalis se encontram protegidas pelo Código do Direito de Autor e Direitos Conexos e demais legislação aplicável, toda a cópia, parcial ou total, deste documento, nos casos em que é legalmente admitida, deverá conter ou fazer-se acompanhar por este aviso. 


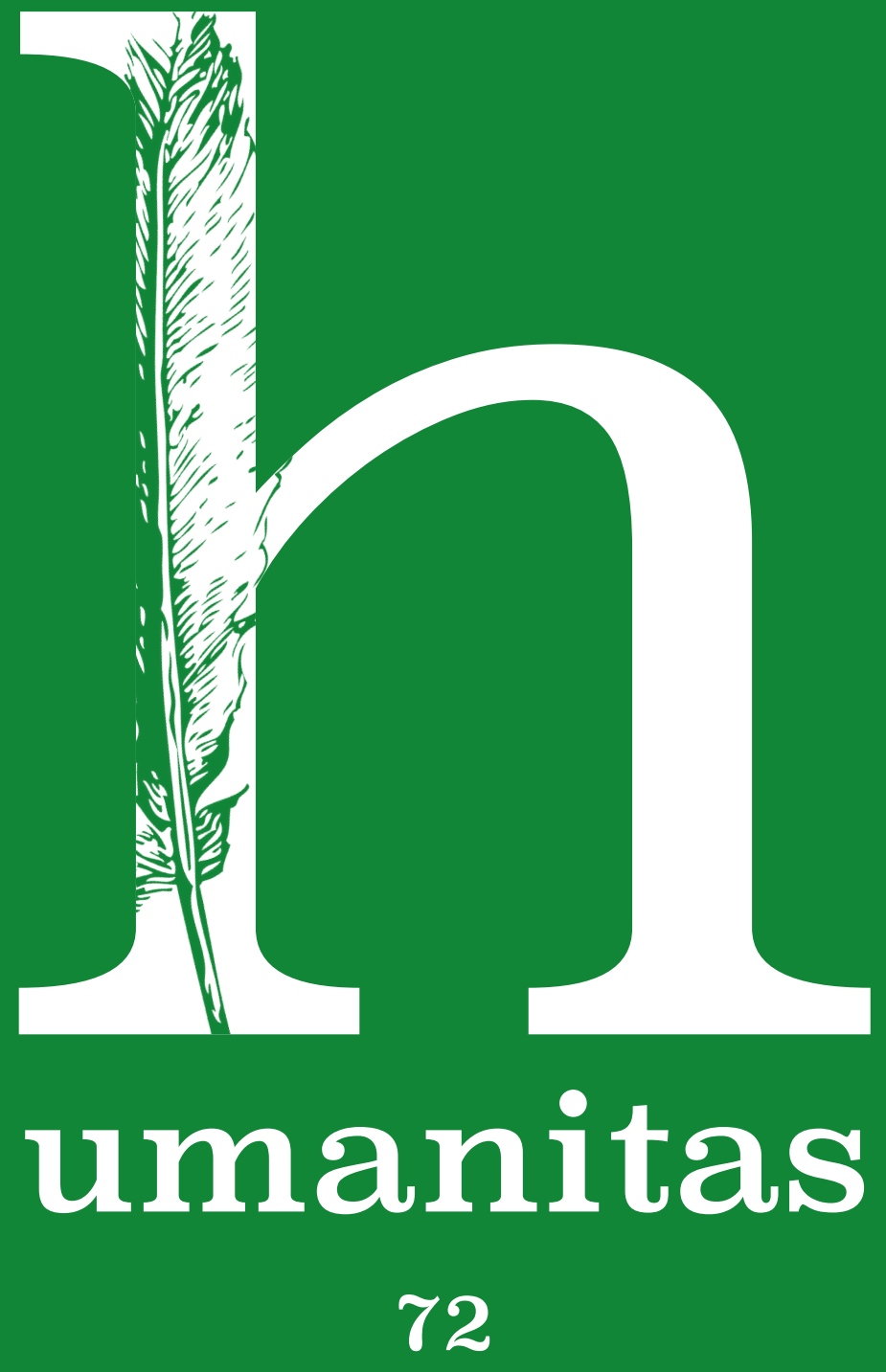

Imprensa da Universidade de Coimbra

Coimbra University Press 


\title{
O USO DO SÍMILE NO POEMA A tomada de TróIa de Trifiodoro ${ }^{1}$
}

\section{The USES OF SIMILE IN Triphiodorus's POEM \\ THE SACK of TROY}

\author{
Johquim Pinheiro \\ pinus@uma.pt \\ Universidade da Madeira \\ Centro de Estudos Clássicos e Humanísticos - Universidade de Coimbra \\ https://orcid.org/0000-0002-5425-9865
}

Artigo submetido a 12-07-2017 e aprovado a 09-11-2017

\section{Resumo}

Propomo-nos analisar o uso do símile no poema épico de Trifiodoro (I $\lambda$ íov $\alpha \lambda \lambda \omega \sigma \iota \varsigma)$. A partir da identificação dos símiles no poema, procuraremos (i) classificá-los por temáticas, (ii) estabelecer uma relação com o contexto narrativo e com a própria estrutura do poema e (iii) comparar o seu efeito retórico com aquele que o símile produz nos Poemas Homéricos. Para enquadrar a dinâmica do símile no poema, será necessário recorrer aos princípios teóricos de alguns tratados ou manuais da retórica clássica.

Palavras-chave: símile; retórica; Trifiodoro; poesia homérica; ciclo troiano.

1 Uma primeira versão deste trabalho foi apresentada nas II Jornadas da Sociedade Portuguesa de Retórica, "Retórica \& Poética", que se realizaram na Faculdade de Letras da Universidade do Porto, em Novembro de 2015. Aos revisores deste texto, expressamos a nossa gratidão pelas várias propostas de melhoria. Este artigo, por opção do autor, não adopta o Acordo Ortográfico da Língua Portuguesa (1990). 


\section{Abstract}

The aim of this paper is analysing how Triphiodorus uses the simile in his epic poem (I I $\lambda$ íov $\alpha \ddot{\lambda} \omega \sigma ı \varsigma)$. After identifying the similes in the poem, we will try to: 1) classify them thematically; 2) establish a relation with the narrative context, and 3) compare its rhetorical effects to the effects created in the Homeric Poems. In order to contextualize the dynamics generated in the poem by the use of the simile, it will be necessary to resort to the theoretical principles established in rhetorical treatises or handbooks.

Keywords: simile, rhetoric, Triphiodorus, homeric poetry, trojan cycle.

Mesmo um leitor menos atento ou pouco preparado não deixa de reparar na elevada frequência com que o aedo homérico recorre à estrutura poética, mais ou menos alongada, de carácter descritivo, em que a acção se suspende, para criar uma analogia, por exemplo, entre a acção de um herói e a de um animal. Esta estrutura designa-se, desde a Antiguidade Clássica, por símile. Enquanto recurso retórico que ornamenta o texto, sobretudo a composição poética, o símile não só mereceu ser objecto de análise teórica, como acabou por se cristalizar como uma característica da épica, em particular de inspiração homérica. Se é verdade que pode ser entendido como uma marca de oralidade poética, o símile assumir-se-ia como um elemento mimético, mas também transformativo, tendo em conta que foi sendo usado de diferentes modos pelos poetas, mas não apenas por estes. Para avaliarmos essa continuidade e transformação, pretendemos analisar como Trifiodoro, no poema $A$ tomada de Tróia, recorre ao símile.

\section{Síntese da teoria retórica sobre o símile².}

Antes de Aristóteles, o símile expressa-se, sobretudo, por meio de

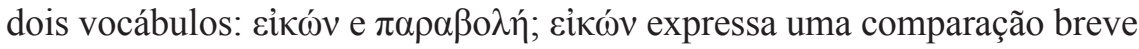
e $\pi \alpha \rho \alpha \beta$ $\lambda \eta ́$ um símile longo. Platão, por sua vez, usa também o vocábulo

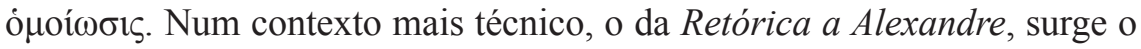

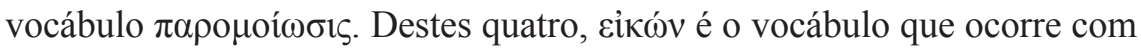
maior frequência. O sentido destes vocábulos remete, de uma forma geral e sem significativas diferenças, para a noção de 'comparação ilustrada'.

2 Para a teorização do símile, vide McCall 1969, Martin 1997, Buxton 2004 e Nünlist 2009. 
É, sobretudo, na Retórica de Aristóteles ${ }^{3}$ que se encontra a primeira tentativa de definição do que se entende por um símile, partindo-se da ideia de que: "O símile é também uma metáfora" ou "[o símile] deve ser utilizado como as metáforas, pois no fundo não passam de metáforas, diferenciando-se no que foi dito" ". Reconhece-se a semelhança com a metáfora, pois tanto o símile como a metáfora, quando bem formulados, conferem elegância ao texto $^{5}$, como peças de ensinamento e conhecimento pelo facto de terem em conta o sentido correcto das palavras. No entanto, para Aristóteles a metáfora torna-se mais agradável para o ouvinte, uma vez que o símile diz o mesmo, mas de forma mais extensa (difere "apenas numa adição" $)$. Nesse sentido, a metáfora, por ser mais breve e não necessitar de adição, é, para o Estagirita, mais elegante. Além disso, considera-se que o símile funciona melhor quando se converte em metáfora, pela analogia de dois termos ${ }^{7}$. Como sucederá em muitos tratados ou manuais de retórica, enfatiza-se a proximidade funcional entre símile e metáfora, pelo efeito comparativo que perseguem, ainda que se realcem diferenças, sobretudo pela sua composição ou forma.

Depois de Aristóteles, também Teofrasto terá escrito sobre o símile, se tivermos em conta a lista de obras que Diógenes Laércio ${ }^{8}$ lhe atribui,

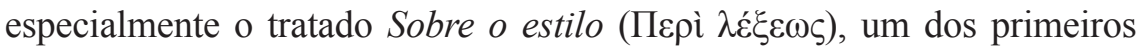
que se dedicou, em exclusivo, à questão da lexis; terá ainda escrito um

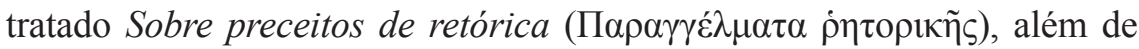

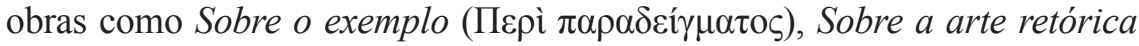

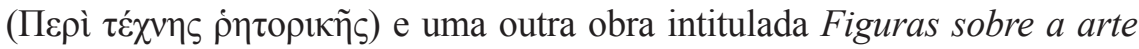

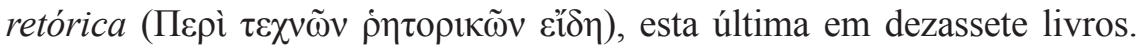
De autoria discutível e de datação incerta, chegou-nos um tratado atribuído a Demétrio, sem rasgos de originalidade, dedicado ao estilo ou elocução (Пєрì $\dot{\varepsilon} \rho \mu \eta \varepsilon i ́ a \varsigma)$, que aborda, ainda que de forma muito breve, o tema do símile?

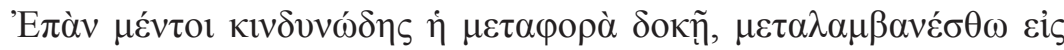

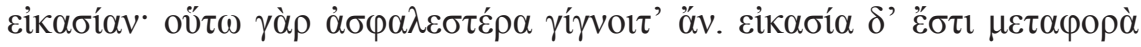
Pena 1998.

Seguimos a tradução de M. Alexande Júnior, P. Farmhouse Alberto e A. Nascimento

$1406 \mathrm{~b}$.

Cf. 1410 b.

Cf. ibidem.

Cf. 1412 b.

Cf. 5.47.

Sobre o Estilo 80. 


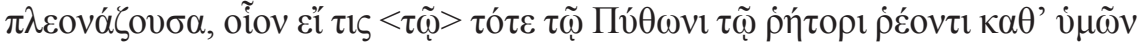

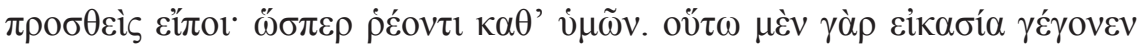

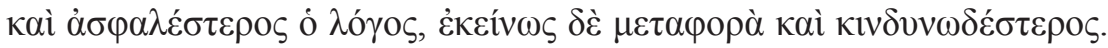

Mas, quando a metáfora possa parecer demasiado arriscada, substitua-se por um símile. Dessa forma, será mais seguro. Um símile é uma metáfora expandida, como se, por exemplo, alguém disser relativamente ao orador Píton que nessa altura ele era "como uma torrente que jorrava sobre vós", em vez de dizer que ele "jorrava torrencialmente sobre vós". Desta forma, fizemos um símile e a expressão tornou-se mais segura, enquanto naquela tínhamos uma metáfora e era mais arriscada.

Assim, segundo Demétrio, o símile (eikasia) distingue-se da metáfora pela sua extensão ("um símile é uma metáfora estendida") e por esclarecer o logos. Refere ainda Demétrio que Platão usou mais metáforas do que símiles, enquanto Xenofonte preferiu os símiles. Acima de tudo, defende-se neste tratado o respeito pela brevidade (brachylogia) ${ }^{10}$, apenas com a introdução da palavra 'como'. Se assim não for, resultarão meras imagens poéticas e não comparações. Esta ideia expressa por Demétrio parece ser um contrassenso, pois aquilo que os poetas pretendem com uma expressão mais dilatada, como o símile, é precisamente conseguir ilustrar o texto. Tal é o valor retórico do símile que, nos Exercícios de Retórica (Progymnasmata) ${ }^{11}$, Hermógenes o inclui, a par do exemplo, na estrutura argumentativa.

Ao abordar as funções da arte da composição, Dionísio de Halicarnasso ${ }^{12}$ afirma que vai esclarecer o que expôs com o recurso a símiles conhecidos, transmitindo a noção do efeito clarificador que o símile pode ter num discurso, desde que o ouvinte consiga descodificar a analogia.

Refira-se que na Retórica a Herénio ${ }^{13}$ se inclui o símile no conjunto das figuras de ornatos, ao nível do exemplo ou da amplificação, uma vez que serve para enriquecer a argumentação. Se, porventura, o símile não estiver completo, ou seja, se lhe faltar a ligação entre os dois elementos ou mesmo um dos elementos, ele é defeituoso, pois não existe uma base de equivalência na comparação ou analogia.

\footnotetext{
10 Cf. 2.89.

11 Cf. 4.40.

12 Sobre a composição literária (De compositione verborum) 6.1-2.

13 Cf. 2.29 .46 .
} 
Por esta síntese se compreende que os autores antigos reconheciam as semelhanças entre símile, metáfora e comparação, mas procuraram explicar as diferenças. Além disso, sem explorarem a complexidade semântica que um símile pode ter, identificaram-no como um dos elementos de reforço argumentativo, também pelo papel que pode desempenhar junto do destinatário do logos. Se muitos dos tratados de retórica escritos durante a Antiguidade não tivessem desaparecido, a teorização sobre o símile conteria certamente mais elementos. Basta recordar que Diógenes Laércio ${ }^{14}$, por exemplo, inclui na vastíssima obra de Crisipo um tratado, em três livros,

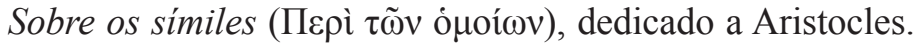

Se o estudo da natureza e da função do símile pode ter começado com Aristóteles, não é difícil de acreditar que foram os bibliotecários de Alexandria que aprofundaram este tema com todo o material literário que tiveram à sua disposição. De Aristarco (século II a. C.) a Eustácio (século XII), os scholia homerica terão desenvolvido uma apurada exegese dos símiles homéricos e exerceram uma grande influência nas escolas de retórica, sobretudo durante o período imperial. Infelizmente, o nosso conhecimento desse vasto corpus de comentários é bastante reduzido. No caso de Eustácio, é reconhecido o seu labor de erudição, como comentador de vários autores clássicos e, em particular, da Ilíada e da Odisseia. Por isso, ganha especial significado o

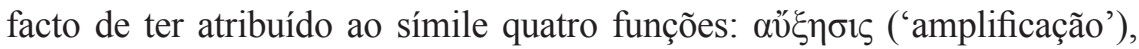

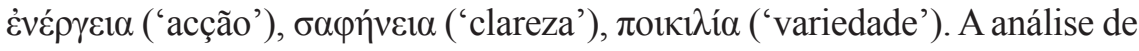
Eustácio continua, de facto, a estar bem presente na filologia dos nossos dias.

\section{O símile na Tomada de Tróia, de Trifiodoro}

Feito este necessário enquadramento teórico, passemos à análise do uso do símile no poema $A$ tomada de Tróia ${ }^{15}$. Retomando uma temática relacionada com o ciclo troiano ${ }^{16}$, com uma longa e riquíssima tradição, Trifiodoro, um grammatikos do século III a. C. pertencente à elite cultural helenizada do Egipto, revela o seu virtuosismo poético. Provavelmente um pouco anterior a Trifiodoro, também Quinto de Esmirna escreveu um poema,

14 Cf. 7.199.

15 Para o texto grego, seguimos a edição de A. W. Mair 1963r, do TLG, salvo indicação em contrário. De enorme utilidade foi o extraordinário estudo e comentário de Miguélez-Cavero 2013 ao poema de Trifiodoro.

16 Não nos parece que o poema possa ser visto como propaganda cultural com vista a celebrar a construção de Constantinopla (324-30), como defende Gerlaud 1982: 6-9. 
mais extenso, com cerca de 8800 versos, em catorze livros, de temática homérica. Outro exemplo da mesma época é o de Nestor de Laranda, autor de uma Ilíada lipogramática, um exercício poético complexo que seria habitual nesta época. Entre as obras atribuídas a Trifiodoro consta uma Odisseia lipogramática, que se terá inspirado, segundo alguns estudiosos, na referida obra de Nestor de Laranda. De facto, a presença dos topoi homéricos e a discussão sobre a historicidade ou não da poesia homérica estão bem presentes na literatura grega do período imperial, em autores como Díon de Prusa, Luciano ou Filóstrato ${ }^{17}$.

No conhecido episódio do canto VIII da Odisseia, o aedo Demódoco, tomando parte do festim, no palácio de Alcínoo, canta três histórias: a primeira sobre a contenda entre Ulisses e Aquiles; a segunda, e mais extensa, sobre os amores de Ares e Afrodite; e uma terceira, a pedido do próprio Ulisses, sobre o ardil do cavalo de madeira. É precisamente esta terceira história que se torna o tema central do poema de Trifiodoro. Do breve canto de Demódoco na Odisseia, ficamos a saber que: foi Epeu que, inspirado por Atena, construiu o cavalo; Ulisses comandou a estratégia de entrar nas muralhas de Tróia; os Troianos, depois de conduzirem o cavalo, para a acrópole, reuniram-se para ponderar o que fazer, tendo colocado três hipóteses: rachar a madeira, arrastar o cavalo para o alto da cidade e atirá-lo contra as rochas, ficar com o cavalo, como oferenda para os deuses; tendo optado por ficar com o cavalo, um terrível destino se abateria sobre a cidade, por acção dos Aqueus. O poema de Trifiodoro descreve, como veremos, mais pormenores sobre este episódio, tal como sucede, por exemplo, na Eneida de Vergílio ${ }^{18}$ ou na épica de Quinto de Esmirna. Trata-se, na verdade, de um processo de extensão ou amplificação de um episódio.

Em 691 hexâmetros, Trifiodoro conta-nos a história do saque de Tróia, desde a captura do adivinho Heleno, filho de Príamo, até à vitória dos Aqueus, em três momentos principais:

1. [ $\tau \dot{\varepsilon} \rho \mu \alpha]$ Alteração no combate (vv. 40-56), com a profecia de Heleno a ditar a ruína de Tróia e a intervenção de Atena;

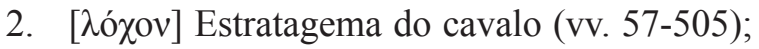

3. [ย̌pls] Combate final (vv. 506-691), a nictomaquia.

$17 \quad$ Vide o estudo de L. Kim 2010.

18 Eneida 2.13-249; Vergílio e Trifiodoro seguem a versão segundo a qual o debate entre os Troianos sobre o que fazer ao cavalo se inicia na planície e não dentro da cidade. 
Comparado com os Poemas Homéricos ou mesmo com a Posthomerica de Quinto de Esmirna, é um pequeno poema com as principais características de um epyllion ${ }^{19}$, ainda que Trifiodoro não dispense o aparato das longas épicas, como o uso do Proémio para invocar Calíope ${ }^{20}$. Quanto ao assunto principal do nosso trabalho, o uso do símile, convém lembrar, por se tratar de um elemento importante e revelador do conhecimento do poeta, que é atribuída a Trifiodoro pela tradição a autoria de uma obra intitulada Paráfrase das parabolai de Homero, provavelmente uma antologia de símiles dos Cantos XVI e XVII da Ilíada, acompanhados de um comentário, semelhante aos dos scholia da Odisseia e Ilíada.

Para facilitar a análise dos símiles no poema A tomada de Tróia de Trifiodoro, apresentamos um quadro resumo:

\begin{tabular}{|c|c|c|c|c|c|}
\hline Trif. vv. ${ }^{21}$ & $\begin{array}{c}\text { Tema na } \\
\text { narrativa }\end{array}$ & $\begin{array}{c}\text { Tema no } \\
\text { símile }\end{array}$ & $\begin{array}{c}\text { Parte estrutural } \\
\text { do poema de } \\
\text { Trifiodoro }\end{array}$ & Tradição $0^{22}$ & $\begin{array}{l}\text { Elementos do } \\
\text { símile }\end{array}$ \\
\hline $\begin{array}{c}152-8 \\
{[\mathrm{~A}]}\end{array}$ & $\begin{array}{c}\text { Neoptólemo } \\
{[1]}\end{array}$ & $\begin{array}{c}\text { Potro } \\
{[2]}\end{array}$ & $\begin{array}{l}\text { Estratagema do } \\
\text { cavalo }\end{array}$ & $\begin{array}{l}\text { Il. 6.506-14, } \\
15.263-9\end{array}$ & $\begin{array}{l}\text { Cavalo } \approx \text { Páris; } \\
\text { Cavalo } \approx \text { Heitor. }\end{array}$ \\
\hline $\begin{array}{c}189-97 \\
{[\mathrm{~B}]}\end{array}$ & $\begin{array}{c}\text { Aqueus } \\
{[2]}\end{array}$ & $\begin{array}{c}\text { Tempestade } \\
{[1]}\end{array}$ & $\begin{array}{l}\text { Estratagema do } \\
\text { cavalo }\end{array}$ & $\begin{array}{l}\text { Il. 4.273-80, } \\
422-8,452-6\end{array}$ & $\begin{array}{l}\text { Movimento da nu- } \\
\text { vem negra (tempes- } \\
\text { tade) } \approx \text { movimento } \\
\text { dos dois Ájax com } \\
\text { os batalhões; ondas } \\
\text { impelidas pelo Zé- } \\
\text { firo } \approx \text { falanges dos } \\
\text { Dânaos; som dos } \\
\text { rios com muito cau- } \\
\text { dal } \approx \text { som do embate } \\
\text { dos homens. }\end{array}$ \\
\hline $\begin{array}{c}219-6 \\
{[\mathrm{C}]}\end{array}$ & $\begin{array}{l}\text { Sínon } \\
{[1]}\end{array}$ & $\begin{array}{c}\text { Caçadores } \\
{[2]}\end{array}$ & $\begin{array}{l}\text { Estratagema do } \\
\text { cavalo }\end{array}$ & Il. 5.487-8; & $\begin{array}{l}\text { Trama preparada por } \\
\text { homens } \approx \text { trama que } \\
\text { parece ter apanhado } \\
\text { os Troianos [aviso de } \\
\text { Sarpédon a Heitor]. }\end{array}$ \\
\hline
\end{tabular}

19 Vide M. Baumbach \& S. Bär 2012.

20 Nos versos 664-7, não refere Calíope, mas usa a designação genérica de 'Musas'.

21 Em anexo, apresentamos os textos acompanhados de uma tradução.

22 Indicamos, sobretudo, paralelos na poesia homérica e no poema épico de Apolónio de Rodes. O que pode ser explorado, num outro contexto, são as semelhanças com a Posthomerica de Quinto de Esmirna. 


\begin{tabular}{|c|c|c|c|c|c|}
\hline $\begin{array}{c}247-9 \\
{[\mathrm{D}]}\end{array}$ & $\begin{array}{c}\text { Troianos } \\
\text { [1] }\end{array}$ & $\begin{array}{c}\text { Gralhas ou } \\
\text { Gaios (aves) } \\
{[2]}\end{array}$ & $\begin{array}{l}\text { Estratagema do } \\
\text { cavalo }\end{array}$ & $\begin{array}{l}\text { Il. 16.582-3, } \\
17.755-7\end{array}$ & $\begin{array}{l}\text { Pátroclo } \approx \text { Falcão; } \\
\text { reacção das gralhas } \\
\text { à proximidade de } \\
\text { um falcão } \approx \text { Aqueus } \\
\text { perante Eneias e } \\
\text { Heitor [fuga]. }\end{array}$ \\
\hline $\begin{array}{c}350-7 \\
{[E]}\end{array}$ & $\begin{array}{c}\text { Troianos } \\
\text { [1] }\end{array}$ & $\begin{array}{c}\text { Grous (aves) } \\
\text { [2] }\end{array}$ & $\begin{array}{l}\text { Estratagema do } \\
\text { cavalo }\end{array}$ & Il. 3.2-9 & $\begin{array}{l}\text { Grito dos Troianos } \\
\approx \text { som dos grous. }\end{array}$ \\
\hline $\begin{array}{c}358-68 \\
{[\mathrm{~F}]}\end{array}$ & $\begin{array}{c}\text { Cassandra } \\
{[1]}\end{array}$ & $\begin{array}{c}\text { Vitela } \\
{[2]}\end{array}$ & $\begin{array}{l}\text { Estratagema do } \\
\text { cavalo }\end{array}$ & $\begin{array}{l}\text { AR. 1.1263- } \\
72\end{array}$ & $\begin{array}{l}\text { Fúria e corrida de } \\
\text { Polifemo Ilátida } \\
\approx \text { reacção de um } \\
\text { touro picado por } \\
\text { um aguilhão; }\end{array}$ \\
\hline $\begin{array}{c}512-21 \\
{[\mathrm{G}]}\end{array}$ & $\begin{array}{c}\text { Helena } \\
{[1]}\end{array}$ & $\begin{array}{c}\text { Lua } \\
{[2]}\end{array}$ & Nictomaquia & $\begin{array}{l}\text { Il. } 8.555-561 \\
\text { QS. } 1.37-40\end{array}$ & $\begin{array}{l}\text { A luz das fogueiras } \\
\text { do Troianos } \approx \text { luz } \\
\text { da lua; Pentesileia } \\
\text { realça-se entre as res- } \\
\text { tantes mulheres } \approx a \\
\text { lua entre as estrelas. }\end{array}$ \\
\hline $\begin{array}{c}533-541 \\
{[\mathrm{H}]}\end{array}$ & $\begin{array}{c}\text { Aqueus } \\
{[1]}\end{array}$ & $\begin{array}{c}\text { Abelhas } \\
\text { [2] }\end{array}$ & Nictomaquia & $\begin{array}{l}\text { Il. 2.87-90, } \\
16.259-65\end{array}$ & $\begin{array}{l}\text { Aqueus a sair das } \\
\text { naus e tendas } \approx \\
\text { abelhas a sair da } \\
\text { "côncava rocha"; } \\
\text { companheiros de } \\
\text { Pátroclo } \approx \text { vespas. }\end{array}$ \\
\hline $\begin{array}{c}542-546 \\
{[\mathrm{I}]}\end{array}$ & $\begin{array}{c}\text { Aqueus } \\
{[1]}\end{array}$ & $\begin{array}{c}\text { Leões } \\
{[2]}\end{array}$ & Nictomaquia & passim & $\begin{array}{l}\text { Ferocidade dos } \\
\text { Aqueus } \approx \text { leões }\end{array}$ \\
\hline $\begin{array}{c}547-551 \mathrm{a} \\
{[\mathrm{J}]}\end{array}$ & $\begin{array}{c}\text { Mulheres } \\
\text { troianas } \\
{[1]}\end{array}$ & $\begin{array}{c}\text { Andorinhas } \\
{[2]}\end{array}$ & Nictomaquia & $\begin{array}{l}\text { Od. } 21.406- \\
411,22.241-2\end{array}$ & $\begin{array}{l}\text { Som da corda do } \\
\text { arco } \approx \text { som da } \\
\text { andorinha; Atena } \\
\text { pousa numa trave } \approx \\
\text { andorinha. }\end{array}$ \\
\hline $\begin{array}{c}613-17 \\
{[\mathrm{~K}]}\end{array}$ & $\begin{array}{c}\text { Ulisses e } \\
\text { Menelau } \\
\text { [1] }\end{array}$ & $\begin{array}{c}\text { Lobos } \\
{[2]}\end{array}$ & Nictomaquia & $\begin{array}{l}\text { Il. } 15.323-6, \\
16.156-67 \\
16.352-6\end{array}$ & $\begin{array}{l}\text { Apolo afugenta os } \\
\text { Aqueus } \approx \text { feras que } \\
\text { atacam manadas } \\
\text { e rebanhos; Mir- } \\
\text { midões } \approx \text { lobos; } \\
\text { Dânaos } \approx \text { lobos. }\end{array}$ \\
\hline $\begin{array}{c}671-5 \\
{[\mathrm{~L}]}\end{array}$ & $\begin{array}{c}\text { Troianos } \\
\text { [1] }\end{array}$ & $\begin{array}{c}\text { Peixes } \\
{[2]}\end{array}$ & Nictomaquia & Od. $22.381-9$ & $\begin{array}{l}\text { Pretendentes mor- } \\
\text { tos } \approx \text { peixes captu- } \\
\text { rados pelas redes } \\
\text { dos pescadores. }\end{array}$ \\
\hline
\end{tabular}


Numa primeira análise, o número de símiles pode parecer reduzido: 12 símiles em 691 versos. E assim é se estabelecermos uma comparação com os 305 símiles da Posthomerica de Quinto de Esmirna (1 a cada 28 versos) ou com a média de um símile a cada 37 versos da Haliêutica de Opiano. Ainda assim, o poema de Trifiodoro tem, em média, um número de símiles um pouco superior ao da épica de Apolónio de Rodes (um em cada setenta e um versos). De realçar que metade dos símiles se encontra na narração da Nictomaquia, aproximadamente os últimos duzentos versos, não havendo uma repartição equilibrada de ocorrências pelas três partes do poema.

A ligação entre os dois elementos do símile não oferece grandes dúvidas: 1) 152-8 - a rapidez com que Neoptólemo adere à estratégia delineada por Ulisses assemelha-se à de um potro que se lança pela planície; 2) 189-97 - tal como o efeito da tempestade no caudal da torrente obriga os animais ferozes a refugiar-se, em silêncio, vencidos pelo susto e enfrentando a fome até que o caudal diminua, assim também os Aqueus suportaram dolorosas penas dentro do cavalo; 3) 219-6 - o dolo de Sínon (o 'herói enganador', 220) é comparado ao dos caçadores que preparam armadilhas para os animais; 4) 247-9 - a reacção dos Troianos ao contemplar o cavalo é idêntica ao som estridente que as gralhas emitem ao ver uma águia; 5) 350-7 - o grito e a disposição dos Troianos enquanto conduzem o cavalo para a acrópole são comparados ao som e ao voo organizado dos grous; 6) 358-68: a vontade de Cassandra em sair dos seus aposentos assemelha-se à rapidez com que a vitela corre depois de picada pelo aguilhão; 7) 512-21 - a bela Helena exibia aos companheiros um archote, da mesma maneira que a lua iluminava o céu; 8) 533-541: os Aqueus saem do cavalo como as abelhas do carvalho, que, após terem feito o seu trabalho, fazem uso dos seus aguilhões; 9) 542-546 - os Aqueus, como os leões, lançam-se sobre os Troianos, espalhando a morte; 10) 547-551a - os gemidos das mulheres troianas, que choram a morte dos seus filhos, são comparados aos sons das andorinhas; 11) 613-17 - a avidez de matança evidenciada por Ulisses e Menelau ao dirigirem-se ao palácio de Deífobo tem equivalência na forma como os lobos atacam um rebanho; 12) 671-5 - tal como os peixes são apanhados pela rede, assim foram dizimados os Troianos.

Desta descrição, resultam vários elementos caracterizadores do símile em Trifiodoro. Desde logo, o facto de a maioria dos símiles ter a presença de animais (9), a que se junta um símile relacionado com a acção da natureza (a tempestade), outro com um elemento celestial (a lua) e, por fim, um sobre homens anónimos que se dedicam à caça. Ao contrário de outras épicas, 
nenhum símile tem a presença de elementos mitológicos, em que a acção dos heróis é comparada à dos deuses. A regra, salvo num dos casos (189-97), é a temática que decorre da narrativa surgir em primeiro. $\mathrm{O}$ facto de termos uma sequência de três símiles (533-541, 542-546, 547-551a) não é um aspecto diferenciador, uma vez que isso sucede também na Ilíada, por exemplo no Canto 2. 466-483 (Aqueus, comandantes e Agamémnon), havendo a salientar, neste caso, a gradação desde o colectivo até um herói em particular.

Quanto à métrica, quisemos verificar se, no poema de Trifiodoro, haveria uma alteração substancial relativamente à poesia homérica. Nos versos em que ocorre o símile, não nos parece ser possível salientar algum uso desmesurado de pés dáctilos ou espondaicos. Embora haja versos em que o quinto pé é espondaico (vv. 222, 354 e 355, 512), não nos parece que isso seja merecedor de especial relevo, por não ser original, além do facto de haver uma tendência na poesia épica do período imperial para esse tipo de ocorrência, ou seja, uma certa tendência para o pé espondaico. De uma forma geral, Trifiodoro usa o verso dáctilo, imprimindo um ritmo mais acelerado ao verso, com sequências em que por vezes temos um pé espondaico.

Voltando a observar a lista de símiles do poema de Trifiodoro, é possível para quase todos eles encontrar um paralelo na poesia homérica. No entanto, o contexto ou a quem se aplica o efeito comparativo variam bastante, exceptuando o caso em que o som dos Troianos é comparado ao dos grous, ainda que no texto homérico não se explore a disposição de voo das aves. Veja-se, por exemplo, o símile que explora a assonância dos vocábulos `E $\lambda \varepsilon ́ v \eta$

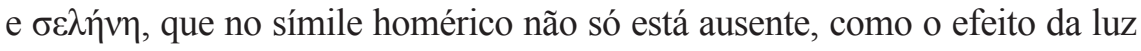
da lua é simplesmente comparada ao das fogueiras que os Troianos acendem (Ilíada 8.555-561). A épica de Quinto de Esmirna (Posthomerica 1.37-40) está, neste símile, mais próxima do sentido que Trifiodoro quis explorar no texto: a imagem da amazona Pentesileia, que se distinguia pelo brilho das outras mulheres, algo que Helena também conseguia.

Estas considerações não pretendem, de modo algum, diminuir o valor paradigmático da poesia homérica para Trifiodoro. Basta ter em conta que $80 \%$ do vocabulário usado é homérico, além dos 115 ä $\pi$ $\alpha$ homéricos e dos $70 \delta i \varsigma \lambda \varepsilon \gamma \delta \mu \varepsilon v \alpha^{23}$. Esta proximidade lexical contribui, parece-nos, para valorizarmos o diferente uso semântico do símile em Trifiodoro. Claro que não podemos ter certezas quanto ao grau de originalidade de Trifiodoro, pois isso seria objeto de melhor avaliação se, por exemplo, a Ilioupersis

23 Cf. Gerlaud 1982: 51-2. 
de Estesícoro tivesse chegado a nós. Depois, são também evidentes as ligações a poetas como Apolónio de Rodes ${ }^{24}$, Vergílio ${ }^{25}$, Opiano ${ }^{26}$ e Quinto de Esmirna. Trifiodoro, como conhecedor da tradição literária de temática homérica, recorreu a processos de adaptação e transformação, em linha com a prática da sua época.

Na comparação com a poesia homérica, há sobretudo duas diferenças a realçar: Trifiodoro confere ao símile um maior realismo e não interrompe a acção para o encaixar ${ }^{27}$. Um dos aspectos que caracteriza o símile homérico é o efeito de contraste, ou seja, o mundo dos deuses e heróis ser assemelhado a actividades tipicamente humanas. Ora, em Trifiodoro esse efeito quase não é explorado, salvo quando o estratagema do herói Sínon é comparado ao de anónimos caçadores. Repare-se, ainda, como Trifiodoro usa os símiles longos para situações mais estáticas, como a caracterização de indivíduos (Neoptólemo, Sínon, Cassandra, Helena, Menelau e Ulisses) ou de grupos (Aqueus e Troianos(as)).

Na verdade, a definição aristotélica continua a fazer todo o sentido: "o símile é também uma metáfora" ou, numa reescrita, a metáfora é um símile elíptico, sendo símile e metáfora manifestações do mesmo fenómeno. Por meio de construções frásicas diferentes, promovem a comparação, com maior ou menor efeito de proximidade. Enquanto elemento microestrutural, o símile acaba por ser uma comparação figurativa. Se um símile funciona bem com personagens desconhecidas ou anónimas (e.g., tal como os homens em combate...assim os leões), no caso do exemplo, figura de elevado valor argumentativo, usam-se personagens que a maioria conhece de modo a que seja mais bem compreendido (e.g., Diomedes corajoso como Aquiles e não Diomedes corajoso como o herói troiano que acompanha Heitor). Sem dúvida, o símile, com grandes

24 Por exemplo, note-se a influência da descrição de Apolónio de Rodes do transporte da nau Argo (1. 362-90), que terá servido de modelo não só a Trifiodoro para descrever a entrada do cavalo em Tróia, mas também a Quinto de Esmirna (12.422-34).

25 Sobretudo a descrição do equus troianus do Canto 2 da Eneida.

26 Miguélez-Cavero 2013: 71 identifica várias semelhanças vocabulares entre Trifiodoro e a Haliêtica de Opiano.

27 Segundo Miguélez-Cavero 2013: 30: “Though in the Iliad extended similes tend to be clustered in action sequences, especially in battles, they are conspicuously absent from the three long descriptions of actions in the Sack of Troy. In these Triph. resorts to quick comparisons, and there are only two long ones, one at the beginning and another at the end of the description, but none in the middle of the action". 
potencialidades líricas, abre ao leitor/ouvinte um espaço com forte sentido figurativo, daí que o texto, mesmo usando poucas palavras, acaba por ganhar uma grande dimensão num espaço não verbalizado. Assim, pode o símile ser considerado um modo de expansão, com efeito suspensivo da acção, que ilumina o texto.

\section{Anexo (textos)}
[A, 152-158]

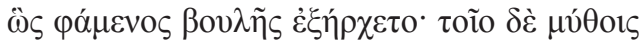

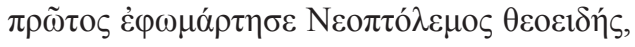

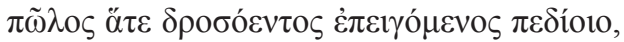

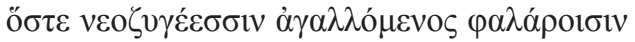

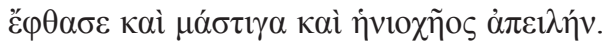

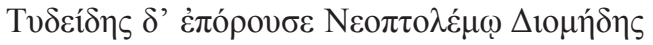

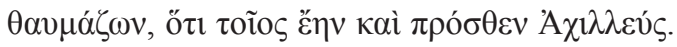
Assim falou [Ulisses] e saiu da assembleia. Estas palavras, em primeiro lugar, seguiu Neoptólemo, semelhante a um deus, como um potro que lançando-se pela húmida planície, exaltado com os adornos colocados no jugo, se antecipou ao açoite e à ameaça do auriga. $\mathrm{O}$ Tidida Diomedes ${ }^{28}$ saltou atrás de Neoptólemo, admirado por ser tão parecido a Aquiles.

[B, 189-199]

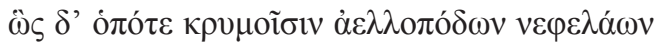

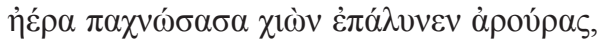

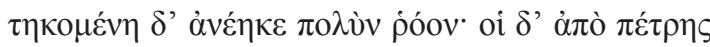

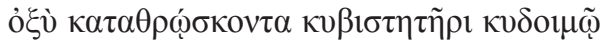

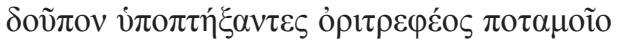

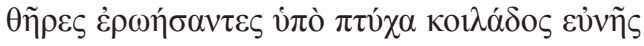

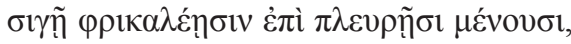

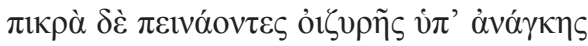

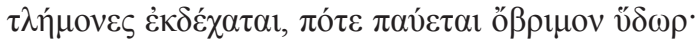

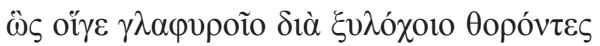

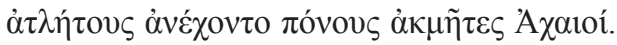

Tal como quando com o frio das nuvens, pés de tempestade,

28 O herói Diomedes só voltará a ser referido no v. 474, não desempenhando um papel relevante na Nictomaquia, ao contrário de Neoptólemo. 
os flocos de neve, gelando o ar, salpicam os campos, ao derreter provocam uma grande torrente. Depois de precipitar-se rapidamente do rochedo com um tumultuoso salto, as feras, por temerem o ruído do rio nascido nas montanhas, refugiam-se no fundo de um covil escavado, onde permanecem, em silêncio ${ }^{29}$, com horríveis flancos, sofrendo uma aguda privação, enquanto, por miserável necessidade, esperam pacientes que cesse a força da água.

Assim os Aqueus que, depois de saltar a côncava cerca, suportavam, infatigáveis, dolorosos sofrimentos.

[C, 219-226]

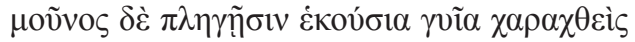

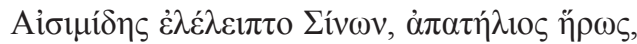

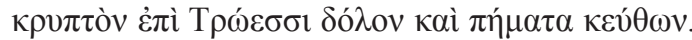

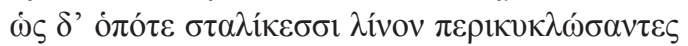

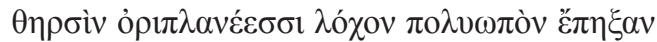

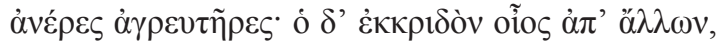

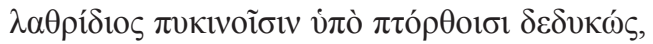

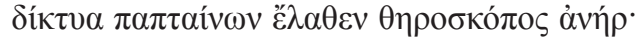
Sozinho, espancando o corpo com golpes, de forma voluntária, ficou Sínon ${ }^{30}$, o Esimida, herói enganador, que ocultava um secreto dolo e sofrimentos para os Troianos. Como quando, prendendo à volta as redes em estacas, os caçadores fixam uma armadilha ${ }^{31}$ para as feras que vagueiam pelos montes. Um só caçador, à parte dos outros, penetrando secretamente por baixo dos densos rebentos, esconde-se, para segurar as redes e ver as feras.

29 Repare-se no contraste entre o silêncio dos animais no covil (194-7), semelhante ao dos heróis dentro do cavalo, e o ruído da torrente (192-3). Na Ilíada 4.452-6, compara-se o barulho da tempestade ao tumulto da batalha.

30 O poema de Trifiodoro refere várias vezes Sínon, um herói ausente dos Poemas Homéricos. Na verdade, o episódio da automutilação de Sínon remete-nos, inevitavelmente, para a mutilação de Ulisses, descrita por Helena (Od. 4.247-8), embora haja várias diferenças. Da mesma forma, também as palavras que Trifiodoro usa para descrever Sínon (por exemplo,

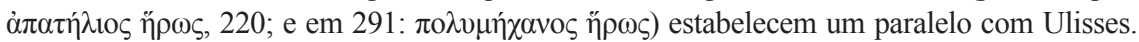
Recorde-se que o uso da mutilação como estratégia para ganhar a confiança do opositor, ou seja, um acto de traição, também é mencionado por Heródoto (3.153-60) em relação a Zópiro.

31 Optamos por não traduzir o adjectivo $\pi$ o $\lambda v \omega \pi$ òv ('com muitos buracos'), que caracteriza 'armadilha', pois essa ideia já é transmitida por 'redes', no verso anterior. 
[D, 247-249 $]^{32}$

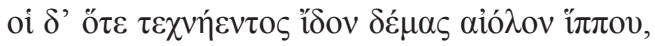

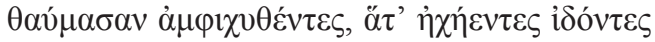

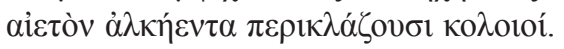

Quando eles [Troianos] viram o corpo variegado do ornado cavalo, rodearam-no espantados, tal como as sonoras gralhas, ao verem uma poderosa águia, fazem barulho em seu redor.

[E, 350-357]

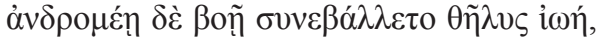

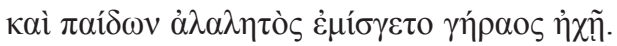

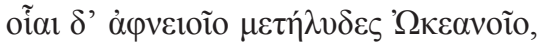

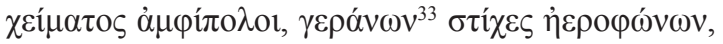

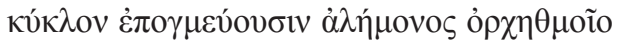

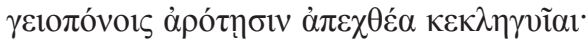

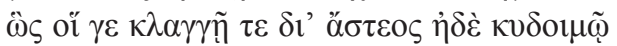

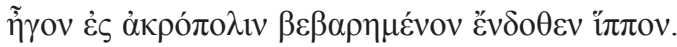
$\mathrm{O}$ grito feminino juntava-se ao clamor masculino, e o gemido das crianças misturava-se com a voz da velhice.

E como as aves do amplo Oceano, servidoras do inverno, os grous que, em fila, ressoam pelos ares e traçam um círculo da sua errante dança, lançando gritos odiosos para os lavradores que trabalham a terra, assim também, entre gritos e tumultos pela cidade ${ }^{34}$, os Troianos conduziam para a acrópole o cavalo carregado no interior.

\section{[F, 358-368]}

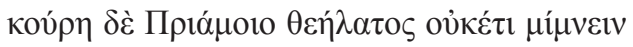

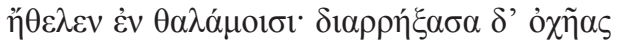

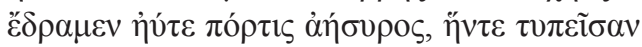

32 O episódio sugere que os Troianos se reuniram em assembleia para debater o que fazer com o cavalo. Na Odisseia (8.505-13), porém, essa reunião ocorre depois de o cavalo entrar em Tróia. Na versão de Trifiodoro, os Troianos consideraram três opções: desfazer à machadada o cavalo; despenhá-lo do alto dos rochedos; deixar ficá-lo no mesmo sítio como oferenda aos deuses. Como sabemos, a má escolha haveria de ditar o cruel destino dos Troianos.

33 Aves que anunciam a estação das chuvas (cf. Il. 3.3-5; Hes. Op. 448-51).

34 Esta reacção dos Troianos resulta do facto de Ulisses e Diomedes terem matado Reso e outros troianos de idade avançada, além de terem libertado os valiosos cavalos dos Troianos (cf. Il. 10.523). 


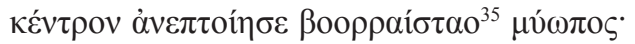

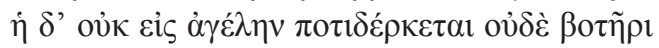

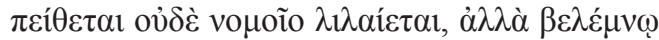

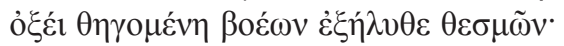

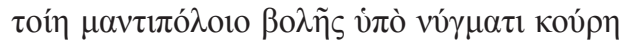

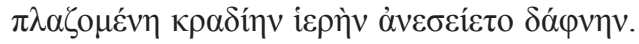

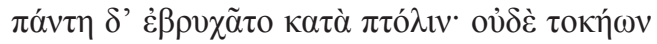

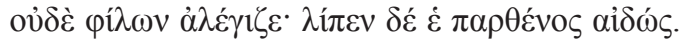
Mas a filha de Príamo $^{36}$, inspirada por um deus, não quis permanecer no tálamo. Depois de quebrar os ferrolhos, correu qual bezerra que salta ligeira, que se espanta quando pisa o aguilhão da espora do matador de bois.

Não olha para o rebanho, nem ao pastor obedece, nem se dedica ao pasto, mas picada com o agudo dardo sai dos lugares habituais. Como a filha que, errando em seu coração por causa da picadela do dardo adivinho, brandia o loureiro sagrado ${ }^{37}$.

Muito ela mugia pela cidade; nem com pais, nem com os amigos se preocupava; pois tinha perdido o pudor virginal.

$[\mathrm{G}, 512-521]^{38}$

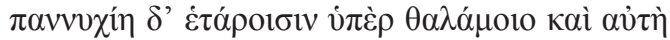

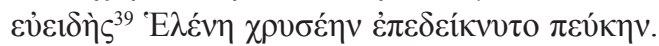

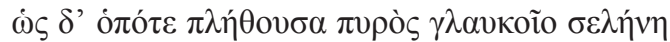

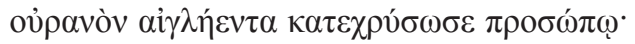

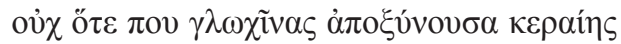

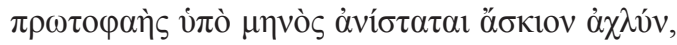

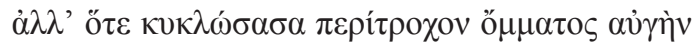

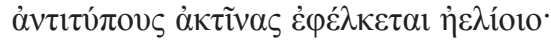

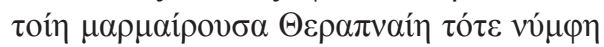

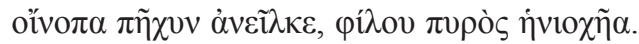
Durante toda a noite, também a bela Helena, do seu tálamo, mostrava aos companheiros a doirada tocha.

35 Trata-se de um hapax.

36 Refere-se a Cassandra.

37 Embora o texto deixe dúvidas sobre a forma como Cassandra agitava o loureiro, com a cabeça ou com o braço, o poeta, por esta via, salienta a ligação entre Cassandra e Apolo.

38 Poderá este símile apoiar-se na comparação de Helena com Ártemis, na Od. 4.121-2.

39 Este epíteto nunca surge associado a Helena nos Poemas Homéricos. 
Como quando a lua, repleta de fogo resplandecente, cobre de ouro o céu brilhante com a face. Não quando, afiando a ponta dos chifres ${ }^{40}$, ao seu primeiro brilho do mês, se eleva numa sombria obscuridade, mas quando, rodeando o brilho circular do olho, atrai os raios reflectidos do sol.

Assim, a jovem de Terapna ${ }^{41}$, brilhando, levantava o braço avermelhado ${ }^{42}$ como guia da chama benévola.

[H, 533-541]

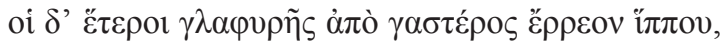

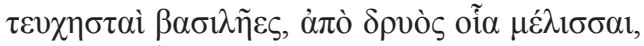

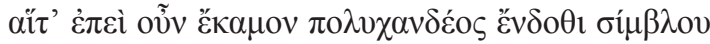

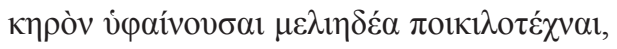

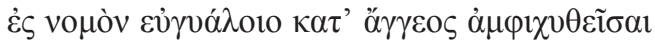

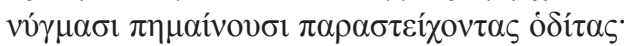

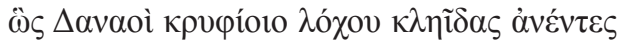

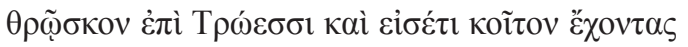

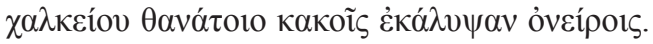
Mas os outros, reis armados, saltaram do ventre oco do cavalo, tal como as abelhas do carvalho, que, depois de trabalharem dentro da espaçosa colmeia, preparam, hábeis em várias artes, a cera como doce mel, e, espargindo para o pasto por um bem arredondado vaso, acometem com picadelas os caminhantes que por ali passam. Assim os Dânaos, abrindo os ferrolhos da oculta emboscada, se lançavam sobre os Troianos e, estando ainda estes no leito, cobriam-nos com funestos sonhos de morte brônzea.

\section{[I, 542-546]}

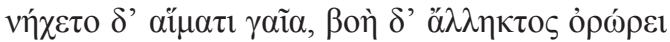

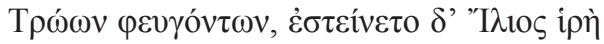

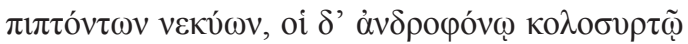

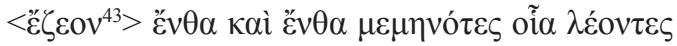

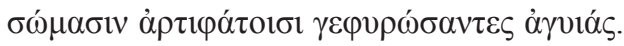

40 Em Arato, Phaen. 785 e 790, surge, no plural, associado à lua ('chifres da lua').

41 Cidade da Lacónia, onde haveria um culto ligado a Helena e aos Dióscoros.

42 À letra: 'cor de vinho'.

43 Em comentário, Miguélez-Cavero 2013 indica outras lições: ěv $\theta 0 \rho o v$, considerada

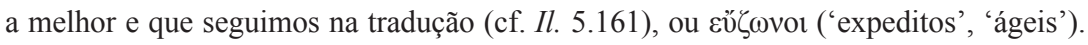


A terra nadava em sangue, o clamor incessante dos Troianos em fuga levantava-se, a sagrada Ílion enchia-se de corpos caídos, enquanto eles [Aqueus], com um trépido assassino, saltavam aqui e ali, em fúria, como leões, fazendo caminhos através dos corpos mortos há pouco.

\section{[J, 547-551a]}

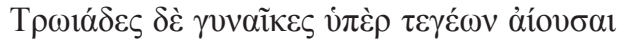

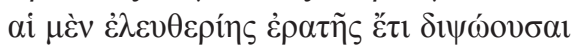

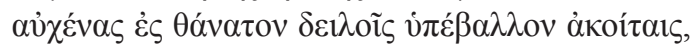

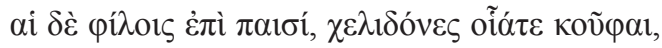

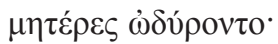

As mulheres troianas ouviam-nos dos seus quartos;

umas ainda ávidas da desejada liberdade oferecem os pescoços para a morte aos desgraçados esposos, as mães, por sua vez, gemiam sobre os queridos filhos, como ligeiras andorinhas.

[K, 613-617]

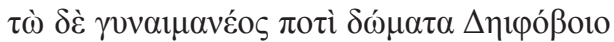

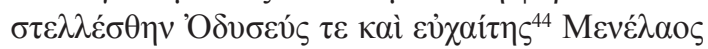

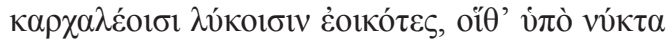

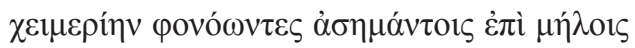

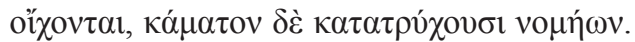
Para o palácio do mulherengo Deífobo dirigiram-se Ulisses e Menelau, de bela cabeleira, semelhantes a lobos de dentes afiados, que numa noite invernosa, ávidos de matar, atacam ovelhas à deriva e devastam o trabalho dos pastores.

[L, 671-675]

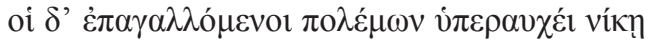

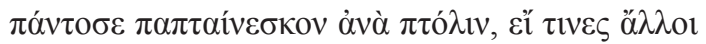

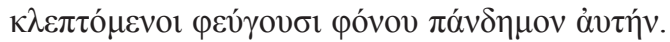

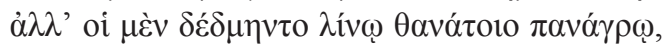

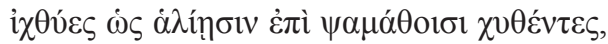
(...).

Eles [os Aqueus], exultantes com a orgulhosa vitória na guerra, olhavam para todas as partes da cidade, caso alguns outros

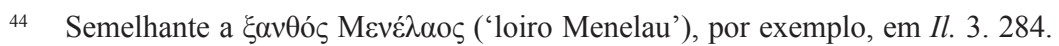


escondidos tivessem escapado da matança de todo o seu povo.

Mas eles tinham sido submetidos pela rede da morte que tudo apanha, como os peixes espalhados pelas areias marinhas, (...).

\section{Bibliografia}

Alexande Júnior, M, Alberto, P. F. \& Pena, A. N. (1998), Aristóteles. Retórica, Lisboa.

Baumbach, M. \& Bär, S. (2012), Brill's Companion to Greek and Latin Epyllion and its Reception. Leiden-Boston.

Bassett, S. E. (1921), “The function of the homeric simile”, TAPA 52: 132-147.

Buxton, R. (2004), "Similes and other Likenesses", in R. Fowler (ed.), The Cambridge Companion to Homer. Cambridge, 139-55.

Gerlaud, B. (1982), Triphiodore, La Prise d'Ilion. Paris.

Israel, M., Harding, J. R. \& Tobin, V. (2004), "On Simile”, in M. Achard \& S. Kemmer (eds.), Language, Culture and Mind. Stanford, 123-135.

Kim, L. (2010), Homer Between History and Fiction in Imperial Greek Literature. Cambridge.

Lourenço, F. (2003), Homero. Odisseia. Lisboa.

Lourenço, F. (2005), Homero. Ilíada. Lisboa.

Mair, A.W. (1963r), Oppian, Colluthus, Tryphiodorus. Cambridge (Ma.) [Thesaurus Linguae Graecae].

Martin, R. P. (1997), "Similes and Performance”, in E. Bakker \& A. Kahane (eds.), Written Voices, Spoken Signs. Tradition, Performance, and the Epic Text. Cambridge (Ma.)-London, 138-66.

McCall, M. H. (1969), Ancient Rhetorical Theories of Simile and Comparison. Cambridge (Ma.).

Miguélez-Cavero, L. (2013), Triphiodorus, The Sack of Troy. A General Study and Commentary. Berlin-Boston.

Nünlist, R. (2009), The Ancient Critic at Work. Terms and Concepts of Literary Criticism in Greek Scholia. Cambridge. 